УДК $821.161 .2-3: 82-93$

Слижук Олеся, кандидат педагогічних наук, доцент Запорізький національний університет

\title{
ТРАГЕДІЯ ВІЙНИ ОЧИМА ДИТИНИ В СУЧАСНІЙ УКРАЇНСЬКІЙ ПРОЗІ ДЛЯ ДІТЕЙ ТА ЮНАЦТВА
}

У статті розкривається проблема відображення воєнних подій крізь призму дитячого сприйняття в сучасних українських прозових творах, призначених для дитячого й підліткового читання. Порівнюються авторські оповідні стратегіі та риси автобіографізму як прийоми художнього письма в повісті В. Рутківського «Потерчата» та в романі С. Жадана «Інтернат». Обтрунтовується, щзо, незважаючи на змалювання воєнних подій із різних часових площин, в сучасній українській прозі простежсується тендениія до вираження думки про війну як трагедію для дитини, дорослого й иілого людства та вітаїстичні погляди на майбутнє.

Ключові слова: воєнна тематика, сучасна проза, оповідна стратегія, автобіографізм.

War tragedy through the child perception in the modern Ukrainian prose for children and youth.

The article reveals the problem of displaying military events through the prism of child perception in modern Ukrainian prose works intended for children and teens reading. Author's narrative strategies and features of autobiography as techniques of artistic writing comparative in 
the story by $V$. Rutkivsky's "Poterchata» and in the novel by S. Zhadan "Internat». It is substantiated that, in spite of the depiction of military events from different time planes, modern Ukrainian prose tends to express the idea of war as a tragedy for a child, an adult and whole humanity, and a vitality view of the future.

Key words: military topics, modern prose, narrative strategy, autobiography.

Тема війни, на жаль, не втрачає своєї актуальності в художній літературі й, зокрема, в літературних творах сучасних українських письменників. Особливо гостро переживають воєнні події люди молодого віку, оскільки війна остаточно руйнує їхні мости з дитинства в дорослість i, не залишаючи вибору, втягує їх у лихоліття. Навряд чи можна говорити про те, що серед сучасних творів воєнної тематики є такі, що спеціально написані для дітей та юнацтва, бо ці, популярні в XX столітті теми - війна, подвиг, героїзм - сучасними дослідниками-літературознавцями й фахівцями 3 інших гуманітарних наук визнані такими, що не входять в коло дитячого читання. Проте останнім часом, iз загостренням військових конфліктів у світі та, що найболючіше, на території України, мимоволі зумовили увагу молодого покоління до художніх творів про них.

Дослідженню творів українських письменників про війну для дітей i юнацтва присвячені праці Т. Качак [Качак 2015], В. Кизилової [Кизилова 2015] та ін. Літературознавці торкаються окремих аспектів цієї проблеми. Аналізуючи твори про Другу світову війну, В. Кизилова зазначає: «Усе ж перевірку живим життєвим досвідом витримали твори інщі: такі, щฺо абстрагувалися від мілітарної тональності, запропонувавии як альтернативу патріотичному та суспільно консолідуючому офіцฺійному образові війни взірияі більш аналітичного підходу до трагедійного досвіду протиборства фашизму $з$ рештою світу. Клішованої ідейності, щзо призвела до швидкоплинної «популярності» текстів, удалося уникнути письменникам, котрі в осмисленні теми воєнного й повоєнного дитинства апелювали до власного життєвого досвіду» [Кизилова 2015 : 41].

До таких творів в сучасній українській літературі належать: «Потерчата» В. Рутківського, «Сектор обстрілу - “Аісти”» I. Моісєєнка, «Війна і ми» С. Пантюка, «Іловайськ» Є. Положія, «Елементал» В. Шкляра, «Інтернат» 
С. Жадана та ін. Більшість творів - про пережиті події сучасного воєнного протистояння на Сході України, але $\epsilon$ проза й про Другу світову i про Афганську війни. Вони, безперечно, є цікавими для дорослого читача, але деякі можуть ввійти й у коло підліткового читання.

Мета статті: проаналізувати проблему відображення воєнних подій крізь призму дитячого сприйняття в сучасних українських прозових творах, призначених для дитячого й підліткового читання, порівнявши авторські оповідні стратегії та риси автобіографізму як прийоми художнього письма в повісті В. Рутківського «Потерчата» та в романі С. Жадана «нтернат».

Повість В. Рутківського «Потерчата» вийшла друком у 2013 році 3 підзаголовком «Дитяча сповідь для дорослих, які так нічому й не навчилися». Ця книга рекомендована для додаткового читання учням 7 класу. Вона детально проаналізована літературознавцями [Качак 2014; Кизилова 2015; Овдійчук 2014; Романенко 2015] та ін. Л. Овдійчук зазначає: «В. Рутківський вибудовує сюжет книги як розповідь (від першої особи) про дитячі роки, щзо припали на передвоєнний період та роки війни. Час означений конкретно, бо така подія зачепила не тільки чоловіків, щзо пішли воювати, жінок, старих людей, які були змушені жити на окупованих територіях, а й дітей, щуо були втягнуті у цеей вир $i$ намагалися вижити, пристосуватися $i$ водночас не забути, щзо вони діти. Місие, де відбуваються події, теж чітко означені: села Пироги на Полтавщ̧ині, Хрестителеве на Киїщуині (тепер Черкащчна) та місиевості, які довелося пройти і проїхати героям. Час і простір описаний через сприйняття дитини, але відтворений уже дорослою людиною, яка осмислила пережите [Овдійчук 2014 : 164].

Роман С. Жадана «Інтернат» надрукований пізніше, відразу привернув увагу читачів i літературних критиків, але ще немає грунтовних літературознавчих досліджень про нього. Він також може ввійти до кола читання учнів 9-11 класів, бо торкається проблем, які хвилюють підлітків: доля i вибір людини у вирі воєнних подій, взаємини батьків і дітей, стосунки 3 однолітками, віра в краще майбутнє. 
Обидва твори описують воєнні події «зсередини», очима очевидців. У «Потерчатах» В. Рутківського нарація ведеться від імені хлопчика Володка, а в «Інтернаті» також один 3 оповідачів - племінник Паші Сашко - вихованець інтернату на окупованій території.

В основі аналізованих творів - мотив подорожі. Трагедія війни в обох творах передається через різноманітні художні деталі, які зафіксовані, перш за все, в топосі творів, який постійно змінюється. У повісті В. Рутківського «Потерчата» початок війни в дитячій пам'яті пов'язаний з проводами батька й картиною далеких пожеж та хрестатих німецьких літаків у небі, які прогуділи кудись на Полтаву. А далі Володика 3 мамою й маленьким братиком чекає дорога - втеча, бо «... германи на танках $і$ мотоииклах вже перебралися через Дніпро $і$ зараз вішають всіх, хто служив совєџькій владі, чи був їхніми родичами» [Рутківський 2013 : 37]. Невдовзі у цій дорозі їх «наздогнала війна». Далі вона асоціюється в дитячій уяві 3 хаосом, скупченням людей, з болем в пораненій об ворожий осколок нозі й постійною втечею й пошуком порятунку. Емоційний стан хлопчика близький до критичного: він відчуває фізичний біль i жаль до себе за те, що «мама вже ніколи не любитиме мене, як любила до війни» [Рутківський 2013 : 49].

Війна стає тією межею, за якою закінчується радісне й безтурботне дитинство й починається час болю, жаху й важких моральних випробувань, які часто не під силу маленькому хлопчикові, тому в якусь мить він навіть бажає смерті своєму крихітному братику Вікторику, бо, може б тоді мама більше уваги й любові приділила йому.

Утеча від війни завершується поверненням додому, але й там чекає прикра несподіванка: рідний дім пограбований, пропали навіть дитячі іграшки. Згодом і свою оселю довелося уступити ворогові, а самим переселитись у клуню.

Страшні події зумовлюють і зміни у психіці дитини: Володя від страху бути вбитим поліцаєм втратив дар мови. Страх проник i у його сни, жахіття переслідують його і вночі: «Цей сон приходив до мене сотні разів. Я прокидався 
від власного крику, корчився від пережитого у моєму сні й чекав, доки за вікном не посірімає. Я не спав цүілими ночами. Бо варто було склепити повіки - як той сон знову приходив до мене» [Рутківський 2013 : 104].

Воєнні події змінюють і односельців Володика, мало хто може заступитись за самотню колишню вчительку з двома малолітніми дітьми. Ті, хто колись прихильно ставився до неї, в жорстоких умовах виживання перетворились у ворогів. Хронотоп дороги в повісті виступає символом шляху до порятунку. Друга мандрівка, яка випала на долю Володі, це шлях до дідуся й бабусі. Як і в першу дорогу, вони вирушають на коні, але цього разу більш впевнено рухаються шляхом, бо їдуть не самі, а везе їх односелець Юрко, та ще й охороняє вірний Песик. Але ще одна трагедія впала на дитяче серце, бо його вірного Песика по дорозі застрілив поліцай.

Недарма повість В. Рутківського «Потерчата» має підзаголовок «Дитяча сповідь для дорослих, які так нічому й не навчилися». Думка про те, що за страшні ігри дорослих чоловіків у війну відповідають невинні скалічені дитячі душі, пронизує твір, є його основною ідеєю, звучить також із уст Володикового діда Кирила «Так вже заведено, щзо за грішних відповідають невинні» [Рутківський $2013: 160]$.

Такий вислів може бути ідеєю будь-якого художнього твору про воєнні лихоліття, зокрема й про сучасну війну на сході України, яка в центрі роману С. Жадана «Інтернат».

Якщо в аналізованій повісті В. Рутківського засудження трагедії війни звучить із уст очевидця подій півстолітньої давнини, то в романі С. Жадана «Інтернат» ця ідея розкривається через детальні описи місцевості, приміщень, в яких скупчена маса людей, що ховаються від вибухів, через вчинки й думки персонажів. Хоч ми й не знаємо впродовж розповіді, хто є наратором, але, очевидно, усі художні деталі зафіксовані очима очевидців, серед яких i підліток - племінник головного героя Паші - Сашко. 
У центрі роману - також дві подорожі: дорога Паші до інтернату і його повернення разом із Сашком додому. Як і в повісті В. Рутківського, в романі «Інтернат» дорога додому є символом порятунку й надії на краще майбутнє.

Композиція роману, фрагментарність епізодів і часта зміна сцен дозволяють віднести цей твір С. Жадана до жанру кіносценарію. Тому всі події зображені крізь призму бачення головного героя, через його оцінки й почуття. У книзі спостерігаємо протиставлення світоглядів - дорослої людини, вчителя Павла й підлітка, його племінника Сашка. Образ Паші уособлює дорослих, які не мають вираженої політичної позиції, тих, кому однаково, якою мовою говорити, хто мало уваги приділяє вихованню дітей і взаєминам зі старшим поколінням. До якогось часу такі, як Паша, живуть у своєрідному вакуумі, не бачать реалій навколо себе. Стимулом для пробудження їхньої свідомості стали межові ситуації - війна, небезпечна дорога окупованою територією. С. Жадан у одному зі своїх інтерв'ю говорив про те, що прототипом Паші $\epsilon$ реальна людина, з якою листувався у 2014 році. Це Ігор, письменник, який живе неподалік Луганська. У першому варіанті твору в основу сюжету покладена історія Ігоря, його думки 3 приводу воєнних подій. Однак в остаточному варіанті автор створив зовсім іншого героя, лише взяв риси свого товариша за листуванням.

Але $є$ й люди, які здатні на подвиг, які живуть заради інших, заради майбутнього. Прикладом таких людей у романі $є$ Ніна, директорка інтернату. На відміну від Паші й більшості другорядних образів роману, вона має чітку суспільну позицію й доводить іншим, що війна - це наслідок байдужості й бездіяльності дорослих людей, які спочатку віддають своїх дітей на виховання в інтернати, а потім і згодні, щоб у їхній країні панували чужі люди, чужі, ворожі ідеї. Саме Ніна і $є$ тією людиною, яка може виховувати молоде покоління і власним прикладом надихає Павла змінитися.

Упродовж основної частини роману розповідається про війну 3 точки зору Павла, тобто тільки фіксується побачене ним у дорозі до інтернату. На останніх сторінках розповідь ведеться від імені Сашка, племінника Паші. 
Вихований в інтернаті, живучи в складних умовах, він не втрачає оптимізму й віри у щасливе майбутнє. Ідучи з дядьком додому, він не тільки не показує страху, але деколи краще за дорослого орієнтується в складних ситуаціях, приймає правильні рішення, не втрачає оптимізму й вірить, що дорога додому буде щасливою, так само, як і дорога всієї України в майбутнє.

Отже, в сучасній українській прозі для дітей та юнацтва $є$ твори про війну, які заслуговують на увагу юних читачів і поважних літературознавців, бо порушують проблеми, які $\epsilon$ актуальними для становлення українського суспільства, відзначаються глибиною осмислення трагедії війни для дітей i дорослих, вражають майстерністю художніх узагальнень. Незважаючи на змалювання воєнних подій із різних часових площин, в сучасній українській прозі простежується тенденція до вираження думки про війну як трагедію для дитини, дорослого й цілого людства та життєствердні, оптимістичні погляди на майбутне.

Перспективами подальших досліджень порушеної у статті проблеми може бути аналіз інших творів сучасних українських письменників про воєнні події з погляду доступності їх для сприйняття читачами середнього й старшого шкільного віку.

\section{БІБЛІОГРАФІЯ}

Жадан 2017 - Жадан С. Інтернат : роман / С. Жадан. - Чернівці : Меридіан Черновіц, 2017. - 336 с.

Качак 2014 - Качак Т. Дискурс дитинства у сучасній українській прозі для дітей та юнацтва : рецептивно-естетичний аспект / Т. Качак // Метаморфози в сучасній українській літературі. - Варшава - Івано-Франківськ, 2014. C. $298-313$.

Качак 2015 - Качак Т. Тема війни і миру в сучасній українській прозі для дітей та юнацтва / Т. Качак // Українська література в загальноосвітній школі. 2015. - № 3. - C. 22-24.

Кизилова 2015 - Кизилова В. Вітаїстичні тенденції у прозі про дітей періоду другої світової війни / В. Кизилова // Науковий вісник Міжнародного 
гуманітарного університету. Серія : Філологія. - 2015. - № 15. - Т. 1. C. $41-44$.

Овдійчук 2014 - Жанрово-стильові особливості сучасної біографічної прози для дітей / Л. Овдійчук // Питання літературознавства. - 2014. Вип. 90. - С. 156-169.

Романенко 2015 - Романенко Л. Творчість Володимира Рутківського у сучасному українському літературному процесі / Л. Романенко // Вісник Маріупольського державного університету. Серія : Філологія. - 2016. Вип. 15. - С. 32-39.

Рутківський 2013 - Рутківський В. Потерчата. Дитяча сповідь для дорослих, які так нічому й не навчилися / В. Рутківський. - Тернопіль : Навчальна книга - Богдан, 2013. - 256 с. 